\title{
O IMPACTO DA DIVERSIDADE CULTURAL NAS POLÍTICAS EDUCACIONAIS: UMA CRÍTICA ÀS PROPOSTAS DAS AGÊNCIAS INTERNACIONAIS
}

\author{
Elma Júlia Gonçalves de Carvalho* \\ Rosangela Célia Faustino*
}

\begin{abstract}
RESUMO
As políticas educacionais de reconhecimento e valorização da diversidade cultural, como as propostas pelas agências internacionais, têm ocupado lugar central nas definições governamentais das três últimas décadas, desafiando educadores e gestores a compreender suas finalidades e buscar novas práticas pedagógicas e administrativas. Tendo em vista o contexto de crise econômica mundial do sistema capitalista, o objetivo neste texto é discutir o histórico do tema da diversidade, remontando ao período posterior à Segunda Guerra Mundial e analisando as orientações internacionais e nacionais produzidas a partir da década de 1990. Ao mesmo tempo, considerando a complexidade educacional decorrente da adoção da perspectiva da diversidade cultural, tentaremos abrir novas perspectivas de análise e de enriquecimento do debate, somando forças no enfrentamento do desafio de se repensar teorias e práticas educativas. Esta é, de nosso ponto de vista, uma forma de contribuirmos para o aprofundamento dos conhecimentos sobre essa temática tão recente na educação e, ao mesmo tempo, tão desafiadora, já que a perspectiva da diversidade, considerada em si mesma, pode ser uma forma de obscurecer o entendimento de como as relações sociais se constituem, contribuindo, em última instância, para a aceitação das diferenças e não para a superação das condições que as produzem.

Palavras-chave: cultura; diversidade cultural; políticas educacionais; crítica.
\end{abstract}

\section{THE IMPACT OF CULTURAL DIVERSITY IN EDUCATIONAL POLICIES: A REVIEW TO THE PROPOSALSOF INTERNATIONAL AGENCIES}

\begin{abstract}
The educational policies of recognition and appreciation of cultural diversity, such as those proposed by international agencies, have occupied central place in government settings over the last three decades, challenging educators and administrators to understand their purpose and seek new teaching and administrative practices. Given the context of the global economic crisis of the capitalist system, the aim of this paper is to discuss the history of the topic diversity, dating from the period after the Second World War and analyzing international and national guidelines produced from the 1990s. At the same time, considering the educational complexity resulting from the adoption of the perspective of cultural diversity, we will try to open up new perspectives for analysis and enrichment of the debate, joining forces in confronting the challenge to rethink theories and educational practices. This is, in our view, a way to contribute to improving knowledge on this topic so recent in education and at the same time, so challenging, since the perspective of diversity, considered in itself, can be a way to obscure the understanding of how social relations are constituted, contributing ultimately to the acceptance of differences and not for overcoming the conditions that produced them.
\end{abstract}

Keywords: culture; cultural diversity; educational policies; review. 


\section{Introdução}

Embora o tema da cultura seja uma preocupação do sistema capitalista desde o final da Segunda Guerra Mundial (UNESCO, 1950), políticas abrangentes de diversidade cultural no campo da educação são recentes. Apresentando-se como uma resposta à crise econômica mundial e aos movimentos sociais, seus termos vêm se tornando cada vez mais marcantes nos documentos internacionais e nacionais, nos debates contemporâneos e nos encaminhamentos das políticas públicas nas últimas décadas do século XX. O tema está associado a conceitos novos, ou renovados, como multiculturalismo, interculturalidade, diferença, identidade, hibridismo e pluralismo, os quais são utilizados na formulação das políticas de inclusão social.

As agências internacionais, a exemplo da Organização das Nações Unidas para a Educação, a Ciência e a Cultura - UNESCO, criadas no contexto da Guerra Fria e consideradas "laboratório de ideias" (UNESCO, 2004, p.33) do sistema capitalista, têm formulado e conduzido, desde o início dos anos de 1990, ações para o controle e a coesão social. Fazem-no por meio de uma política de diversidade cultural e de inclusão, na qual são destacados os grupos considerados vulneráveis: indígenas, afrodescendentes, deficientes, jovens e mulheres pobres.

Os países membros da Organização das Nações Unidas - ONU têm sido convocados para formular decisões a ser adotadas em diferentes regiões do mundo. $\mathrm{Na}$ América Latina, desde o final dos anos de 1970, no contexto de avanço e de expansão do capitalismo, ou seja, no da globalização e da adoção do neoliberalismo como modelo econômico e político, realizam-se eventos e elaboram-se documentos de orientação para a formulação de uma nova política educacional.

La Conferencia Regional de Ministros de Educación y de Ministros Encargados de la Planificación Económica de los Estados Miembros de América Latina y del Caribe, convocada por la UNESCO y reunida en México, D.F., del 4 al 13 de diciembre de 1979, se ha efectuado en un ambiente altamente positivo de consenso sobre el crucial momento histórico que viven los países de la región en la coyuntura mundial, con clara conciencia de que ha llegado una nueva etapa para la afirmación solidaria de la propia cultura y para asumir plenamente el destino de los pueblos de esta parte del globo (UNESCO, 1979, p.1).

A nova fase do capitalismo viabilizou a ampla difusão do ideário de respeito e valorização da diversidade e a construção pactuada de uma política universal fundada nos princípios da identidade dos grupos e da diferença. Os objetivos encontram-se expostos na Declaración de México sobre las Políticas Culturales, formulada no âmbito da Conferência Mundial sobre as Políticas Culturais ocorrida em 1982. Nesse texto, está contida a ideia de que as nações têm se confrontado com graves dificuldades econômicas e de que, em face da desigualdade crescente entre elas, muitos conflitos e tensões graves ameaçam a paz e a segurança de todos. É por essa razão que, segundo o documento, foram sistematizados princípios orientadores de políticas culturais voltadas ao fortalecimento da coesão social.

Em outro documento, Informe mundial sobre a cultura: diversidade cultural, conflito e pluralismo, publicado em 2000 pela UNESCO, consta que a maior parte dos conflitos que surgem nos Estados-nação tem um componente cultural e que tais conflitos são um obstáculo para o desenvolvimento. Mais recentemente, no Relatório Investir na 
Diversidade Cultural e no Diálogo Intercultural, publicado em 2010 pela UNESCO, fica anunciado:

É urgente investir na diversidade cultural e no diálogo. Com efeito, integrar a diversidade cultural numa ampla série de políticas públicas incluindo as que estão por vezes bastante afastadas das políticas culturais propriamente ditas - pode contribuir para renovar as abordagens da comunidade internacional relativamente aos dois objetivos-chave que são o desenvolvimento e a busca da paz e prevenção dos conflitos (UNESCO, 2010, p.31).

Por meio de resoluções, leis, diretrizes, referenciais, currículos, materiais didáticos e cursos de formação de professores, tais políticas de valorização e reconhecimento da diversidade têm chegado às salas de aulas. Assim, os profissionais da educação têm se visto na necessidade de lidar direta e cotidianamente com situações nas quais a diferença assume cada vez mais relevância. Educadores e gestores são, portanto, levados a promover estudos aprofundados, reflexões, debates, e, principalmente, mudanças na prática pedagógica.

Neste artigo, considerando o contexto de crise econômica mundial do sistema capitalista, o objetivo é discutir o histórico do tema da diversidade, com foco especial nas orientações internacionais e nacionais produzidas a partir da década de 1990. Em face do grande impacto dessas orientações no campo educacional e da complexidade inerente à adoção da perspectiva da diversidade cultural, tentaremos oferecer novas possibilidades de análise dessa temática tão recente na educação e, ao mesmo tempo, tão desafiadora. A finalidade é somar forças no desafio presente na tarefa de se repensar teorias e práticas educativas.

O texto está dividido em quatro itens. No primeiro, discutimos as transformações do conceito de cultura e de diversidade cultural e as razões históricas da relevância atribuída ao tema nas últimas décadas do século XX. No segundo, retomamos o discurso de reconhecimento e valorização da diversidade cultural utilizado desde o final da Segunda Guerra Mundial e reafirmado até o final da década de 1980, quando passou a ter centralidade nas políticas educacionais internacionais e nacionais. O terceiro item é dedicado a mostrar como o tema aparece em alguns documentos internacionais e nacionais produzidos a partir desse momento: inicialmente, descrevemos os aspectos educacionais contidos nos documentos produzidos pelas agências internacionais e, em seguida, fazemos uma síntese dos que foram produzidos no Brasil. Na análise realizada no último item, procuramos desenvolver a hipótese de que um projeto de educação fundado em tais orientações pode ocultar as contradições sociais, dificultando uma compreensão histórica da desigualdade real e dos interesses antagônicos inerentes à sociedade atual.

\section{Cultura e diversidade cultural}

Etimologicamente falando, o conceito de cultura relaciona-se à natureza: tem origem no latim colere e significa o ato de "cultivar", de fazer a terra produzir o necessário, ou seja, refere-se à produção agrícola. No entanto, ao longo do tempo, o termo foi assumindo outros sentidos, mais amplos e dinâmicos, dando margem a entendimentos diferenciados.

Raymond Williams (2011, p.18), teórico que investigou parte da complexa história da palavra cultura, informa que, antes do século XIX, ela significava, primordialmente, a "tendência a crescimento natural" e, desde então, foi adquirindo novos significados. De 
“"um estado geral ou hábito da mente' tendo relações próximas com a perfeição humana", passou a significar "uma situação geral de desenvolvimento intelectual em uma sociedade como um todo", posteriormente, um "corpo geral das artes" e, finalmente, "todo um modo de vida, material, intelectual e espiritual".

$\mathrm{Na}$ segunda metade do século XX, o conceito adquiriu maior amplitude, sendo relacionado às produções artísticas e filosóficas e, em decorrência de uma convergência prática entre o sentido antropológico e o sociológico, passou a incorporar

[...] por um lado, como um "modo de vida global" distinto, dentro do qual se desenvolveria um "sistema de significações" orientando a atividade social e, por outro lado, o sentido mais especializado de cultura com ênfase em um sistema de significações geral, como "atividades artísticas e intelectuais", ainda que, a partir de então, incorporasse outras "práticas significativas", "desde a linguagem, passando pelas artes e filosofia, até o jornalismo, moda e publicidade", que constituiriam um "campo complexo e necessariamente extenso" (SILVA, s/da, p.2).

Com essas novas abordagens, cultura passou a ser identificada com discursos múltiplos, bem como com histórias distintas. Para Eagleton (2005, p.53), "cultura significa tudo que é humanamente construído ao invés de naturalmente dado". Ou seja, cultura seria tudo aquilo que se pode produzir historicamente, por meio das relações materiais estabelecidas, ou seja, pelos seres humanos em sociedade. Isso envolve compreender que "o conceito guarda um tensionamento com a materialidade das relações sociais e se imbrica nas lutas ideológicas e políticas" (SILVA, s/db, p.4).

Eagleton (2005, p.60) observa que o termo passou por alterações importantes, pois, tradicionalmente, cultura "designava valores que compartilhávamos [enquanto sujeitos universais] simplesmente em virtude de nossa humanidade comum". Entretanto, desde a década de 1960, em virtude de um deslocamento conceitual, "a palavra 'cultura' foi girando sobre seu eixo até significar quase exatamente o oposto": "a afirmação de uma identidade específica - nacional, sexual, étnica, regional", ou seja, os modos e estilos de vida, costumes e valores dos grupos sociais específicos.

É nessa acepção, isto é, como especificidade dos diferentes grupos humanos, que, na atualidade, a cultura adquiriu relevância, integrando as orientações das organizações internacionais, os discursos de chefes de Estado, a mídia, as reivindicações dos "novos" movimentos sociais (das mulheres, dos negros, dos índios, dos homossexuais, das minorias étnicas ou lingüísticas ou regionais, etc.) e a agenda política da direita e da esquerda ${ }^{1}$.

Segundo o antropólogo Adam Kuper (2002, p.288), "a cultura está mais em voga do que nunca", abrangendo as mais diversas partes do mundo e os mais variados setores da sociedade. O termo tornou-se politicamente correto, sendo usado como forma de falar sobre identidades coletivas tanto por "pesquisadores de mercado em Londres, para um magnata japonês, pelos habitantes da Nova Guiné e para um religioso radical do Teerã" (KRUPER, 2002, p.24).

O sentido da relevância adquirida pela cultura e pela diversidade cultural nos últimos anos é explicado por Eagleton (2005, p.41-42) da seguinte maneira:

[...] Como idéia, a cultura começa a ser importante em quatro pontos de crise histórica: quando se torna a única alternativa aparente a uma sociedade degradada; quando parece que, sem uma mudança social profunda, a cultura no sentido das artes e do viver não será mais nem mesmo possível; quando fornece os termos nos quais um grupo ou povo 
busca sua emancipação política; e quando uma potência imperialista é forçada a chegar a um acordo com o modo de vida daqueles que subjuga.

O mesmo autor afirma que as mudanças recentes vivenciadas pelo sistema capitalista elevaram a ideia de cultura a primeiro plano. À medida que houve um enfraquecimento das políticas de classes, que o mundo colonizado passou a vivenciar a era da liberalização nacional e que amplos setores do globo foram sendo "reconstruídos por uma corrente política - o nacionalismo revolucionário - cujas raízes estavam profundamente inseridas na ideia de cultura" e que "as forças de mercado penetraram mais profundamente na produção cultural", a cultura ganhou renome (EAGLETON, 2005, p.178-179).

Para Ahmad (2002, p.9), é surpreendente que, exatamente no momento histórico em que, pela primeira vez, o capitalismo penetrou nos âmbitos mais longínquos não só das produções econômicas, mas também no das produções culturais, houvesse surgido uma ideologia de deslocamento do locus de determinação da economia política para a cultura.

Na interpretação de Wood (2011, p.219), a ênfase na diversidade, na "diferença" e no pluralismo decorre do fato de que as relações sociais do capitalismo se dissolveram em uma pluraridade fragmentada e desestruturada de identidades e diferenças. Ou seja, "[...] a sociedade contemporânea se caracteriza por fragmentação crescente, diversificação de relações e experiências sociais, pluralidade de estilos de vida, multiplicação de identidades pessoais". Por essa razão, "[...] Romperam-se as velhas solidariedades de classe - e proliferam movimentos sociais baseados em outras identidades e contra outras opressões, movimentos relacionados à raça, ao gênero, à etnicidade, à sexualidade etc." (WOOD, 2011, p.220).

Ao abordar a relação entre imperialismo e cultura no capitalismo contemporâneo, Silva chama a atenção para o papel de destaque que nela desempenham as agências internacionais, particularmente a UNESCO. Nas três últimas décadas, essa agência tem atuado tanto "na ampliação do conceito de cultura ${ }^{2}$, como também na articulação de uma rede internacional de organizações não governamentais (ONGs), áreas empresariais e inúmeros governos, no sentido da constituição de políticas públicas culturais" (SILVA, s/da, p.1).

Para o autor, a ênfase que os conceitos de cultura, diversidade e direitos culturais têm recebido é explicada tanto pelos "interesses do imperialismo em seu conjunto como também pelas contradições inter imperialistas em fase de suas recorrentes crises políticas e econômicas acentuadas a partir da década de 1970" (SILVA, s/db, p.2). Nesse quadro político internacional,

[...] as agências multilaterais, como a UNESCO, recorreram cada vez mais à idéia de paz e harmonia entre os povos, nações e grupos minoritários. Podemos citar três coordenadas como exemplos: a) disputa políticoideológica entre imperialismo e bloco socialista, nas tensões decorrentes da Guerra Fria, e também as guerras de libertação nacional na África; b) conflitos inter-imperialistas em disputas de interesses por mercado, inclusive para a voraz indústria cultural estadunidense, que se acentuou nas últimas décadas; c) predominância estadunidense, após o colapso político do Bloco Soviético, sobre os crescentes conflitos políticos, étnicos e de nacionalidades por meio de inúmeras intervenções militares para garantir a geopolítica imperialista (SILVA, s/db, p.2). 
A ênfase nas especificidades culturais foi estratégica para reorganizar o processo de expansão do sistema de mercado, especialmente nos países do leste europeu depois da extinção da União Soviética. Essa ênfase está relacionada tanto às novas formas de gerir os conflitos sociais (CARVALHO, 2012) quanto ao processo de mercadificação. Como descreve Harvey (2011, p.178), “[...] A mercadificação pressupõe a existência de direitos de propriedade sobre os processos, coisas e relações sociais, supõe que se pode atribuir preço a eles e negociá-los nos termos de um contrato legal [...]". Ou seja, "equivale a atribuir um preço a coisas que na verdade jamais foram produzidas como mercadorias" (HARVEY, 2011, p.179), a exemplo da cultura.

Em razão do que apontam os autores, podemos compreender alguns fatores que justificam a centralidade do reconhecimento e da valorização da diversidade cultural nos atuais encaminhamentos políticos, particularmente no campo educacional.

O termo diversidade cultural também incorpora um amplo conjunto de definições e conceitos, cujo escopo é extremante variado. Em geral, diz respeito à multiplicidade de ideias, hábitos, valores, crenças, comportamentos e características espirituais e materiais, intelectuais e emocionais que definem os diferentes grupos humanos, atribuindo-lhes identidade em um determinado tempo e território. Segundo Oliveira e Souza (2011, p.128):

A diversidade cultural engloba diferenças culturais que existem entre as
pessoas, como linguagem, danças, vestimenta e tradições, bem como a
forma como as sociedades organizam-se conforme a sua concepção de
moral e de religião, a forma como eles interagem com o ambiente, etc.. O
termo diversidade diz respeito à variedade e convivência de ideias,
características ou elementos diferentes entre si, em determinado assunto,
situação ou ambiente.

Portanto, a ideia de diversidade cultural encontra-se relacionada "aos conceitos de pluralidade, multiplicidade, diferentes ângulos de visão ou de abordagem, heterogeneidade e variedade. E, muitas vezes, também, pode ser encontrada na comunhão de contrários, na intersecção de diferenças, ou ainda, na tolerância mútua" (OLIVEIRA; SOUZA, 2011, p. 128).

$\mathrm{Na}$ perspectiva da UNESCO, o termo diversidade cultural sofreu variações de significado ao longo da história. Acomodando-se às mudanças políticas e sociais, o tema faz parte das principais preocupações sociais da atualidade3. Em documento recente, a palavra é usada para definir a multiplicidade de meios pelos quais se expressam os diferentes grupos sociais e sociedades. Assim, por diversidade cultural entende-se não apenas a diversas formas pelas quais se expressa, se enriquece e se transmite o patrimônio cultural da humanidade, mediante a variedade de expressões culturais, mas também os distintos meios de criação, produção, difusão e distribuição e consumo (UNESCO, 2005, III, Art. $4^{\circ}, \S$ I).

Nos Parâmetros Curriculares Nacionais - Pluralidade Cultural (BRASIL, 1997), o termo encontra-se definido da seguinte maneira:

As culturas são produzidas pelos grupos sociais ao longo das suas histórias, na construção de suas formas de subsistência, na organização da vida social e política, nas suas relações com o meio e com outros grupos, na produção de conhecimentos etc.. A diferença entre culturas é fruto da singularidade desses processos em cada grupo social (BRASIL, 1997, p.19). 
Evitando comprometer a ordem do capitalismo e sua expansão, os organismos e agências internacionais não caracterizam os movimentos sociais revolucionários e de protestos como ações contra a pobreza e a exclusão geradas pelo sistema e sim como movimentos culturais. É nesse sentido que propõem uma plataforma de tolerância, reconhecimento e inclusão, por meio da qual seria obtida a conciliação social no mundo.

Para alguns, a diversidade cultural é intrinsecamente positiva, na medida em que se refere a um intercâmbio da riqueza inerente a cada cultura do mundo e, assim, aos vínculos que nos unem nos processos de diálogo e de troca. Para outros, as diferenças culturais fazem-nos perder de vista o que temos em comum como seres humanos, constituindo assim a raiz de numerosos conflitos (UNESCO, 2013, INTRODUÇÃO).

Nesses termos, a diversidade cultural é apresentada como algo novo e positivo que deve ser afirmado, reconhecido e protegido. Ela "cria um mundo rico e variado que aumenta a gama de possibilidades e nutre as capacidades e valores humanos, constituindo, assim, um dos principais motores do desenvolvimento sustentável das comunidades, povos e nações", sendo "indispensável para a paz e a segurança no plano local, nacional e internacional" (UNESCO, 2005, p.1), o que justificaria a iniciativa de "incorporar a cultura como elemento estratégico das políticas de desenvolvimento nacionais e internacionais" (UNESCO, 2005, p.1).

\section{O discurso internacional de reconhecimento e valorização da diversidade cultural entre 1945 e 1990}

Como vimos no item anterior, o tema do reconhecimento e do respeito à diversidade cultural adquiriu centralidade nas políticas elaboradas nas décadas finais do século XX, mas, de fato, esse discurso remonta ao final da Segunda Guerra Mundial, quando a discussão sobre raça, racismo, discriminação e etnocentrismo redirecionaram seu significado (UNESCO, 1950).

A UNESCO, fundada em 1945, teve como objetivos primordiais combater os fascismos e as revoluções comunistas que colocavam em risco o sistema capitalista e promover a tolerância e o controle dos movimentos sociais, mediante a educação, a ciência, a cultura e as comunicações 4 .

Conforme Faustino (2006), as atividades iniciais dessa agência foram convenções internacionais, das quais participavam personalidades importantes, dentre as quais o eminente antropólogo francês Claude Lévi-Strauss, que foi convidado para abordar questões culturais.

Combatendo as correntes teóricas predominantes no período, Lévi-Strauss (1976) contestou a utilização do conceito de raça, assentado no determinismo biológico, e, discutindo a importância de se compreender as diferenças, defendeu o conceito de cultura, por considerá-lo mais apropriado e coerente para aplacar as rivalidades e a violência geradas no contexto das guerras.

$\mathrm{Na}$ ocasião, Lévi-Strauss discursou sobre a diversidade humana e posicionou-se a respeito da necessidade de se reconhecerem as diferenças culturais existentes no mundo. Para responder ao eurocentrismo, argumentou que existiam '[...] nas sociedades humanas simultaneamente, em elaboração, forças trabalhando em direções opostas: umas tendem à manutenção, e mesmo à acentuação dos particularismos; as outras agem no sentido da convergência e da afinidade" (LÉVI-STRAUSS, 1976, p.331).

Seu discurso foi amplamente divulgado pela UNESCO, iniciando-se, assim, a 
discussão que daria origem à ideia de diversidade cultural como um contraponto aos nacionalismos exacerbados e ao movimento nazi-fascista na Europa.

Desde o final da Segunda Guerra Mundial, a Organização das Nações Unidas (ONU), por meio de suas agências, tem publicado documentos a respeito do tema. Em 1948, por exemplo, foram aprovadas a Declaração Universal dos Direitos Humanos e a Convenção sobre a Prevenção e Repressão do Crime de Genocídio. No entanto, foi apenas nos anos de 1990, em razão da crise estrutural do capitalismo, evidenciada desde meados da década de 1970, que o tema adquiriu centralidade nas políticas. A partir desse momento, destaca-se uma legislação especial e particularizada de amparo e proteção a determinados grupos em situação considerada como de vulnerabilidade.

A crise econômica mundial fez aumentar o desemprego e a exclusão social, forçando as economias centrais não apenas a reafirmar a importância da inclusão, mas também a elaborar políticas de reconhecimento e tolerância para com a diferença, visando, principalmente, a coesão social.

Fundamentando-se no multiculturalismo e na interculturalidade, a política da diversidade alude ao direito de os sujeitos serem reconhecidos e tratados como diferentes. Essa política tem como fundamento o 'liberalismo humanitário' 5 (CALLINICOS, 1995), em cuja caracterização reverberam as ideias de John Locke, contidas em sua Carta sobre a tolerância, escrita em $1689^{6}$ (FAUSTINO, 2006).

A ideia foi disseminada pela UNESCO entre inúmeros países: modificando conceitos e adquirindo muitos seguidores, tornou-se pauta em eventos internacionais e publicações científicas em diferentes línguas.

O 'multiculturalismo', conceito elaborado nos Estados Unidos e implantado como política de governo no Canadá nos anos de 1970, onde se reconhecia legalmente a existência de diferentes grupos linguístico-culturais, tornou-se parte das estratégias governamentais para negociar e controlar os movimentos sociais.

Nos países em que se aplica como plataforma política de negociações, o multiculturalismo apresenta facetas diferentes. $\mathrm{Na}$ área da educação, por exemplo, vêm sendo determinados às escolas o acolhimento, a tolerância e a presença de línguas e conteúdos diversificados nos currículos.

Nos Estados Unidos, o termo foi utilizado no contexto das lutas do movimento negro e feminista pela igualdade de direitos civis, pelo fim da segregação racial, pela inserção equitativa no mercado de trabalho e pelo acesso à educação. Nesse país, foram implantadas as primeiras políticas de ações afirmativas ${ }^{7}$, inicialmente direcionadas à população negra, posteriormente, às mulheres, depois, a algumas minorias éticas e a estrangeiros.

Em 1965, a ONU aprovou a Convenção sobre a Eliminação de Todas as Formas de Discriminação Racial". No preâmbulo, consta: "Alarmados por manifestações de discriminação racial ainda em evidência em algumas áreas do mundo e por políticas governamentais baseadas em superioridade racial ou ódio, como as políticas de apartheid, segregação ou separação", os Estados participantes almejavam assegurar "todas as medidas necessárias para eliminar rapidamente a discriminação racial em todas as suas formas e manifestações, e a prevenir e combater doutrinas e práticas racistas e construir uma comunidade internacional livre de todas as formas de segregação racial e discriminação racial" (UNESCO, 1968, p.1).

Em 1979, esse discurso inspirou a adoção da Convenção sobre a Eliminação de Todas as Formas de Discriminação contra a Mulher ${ }^{9}$ pela ONU.

Conforme Faustino (2006), nos anos de 1970, após estudos encomendados por diferentes governos norte-americanos, o multiculturalismo foi adotado como uma política 
governamental, por meio tanto de uma legislação de proteção e de promoção dos direitos fundamentais dos grupos minoritários, quanto de políticas de ações afirmativas, as quais funcionaram como mecanismos de incentivo a grupos discriminados e de manutenção equilibrada das forças antagônicas da sociedade.

Tanto no Canadá quanto nos Estados Unidos, a política do multiculturalismo, de uma perspectiva de assimilação das culturas minoritárias passou para a exaltação da diversidade como uma característica positiva das sociedades modernas. Dessa perspectiva, foi proposto o reconhecimento da filiação do indivíduo ao seu grupo cultural, ressaltando o respeito às diferenças como elemento importante para se alcançar a tolerância, combater o racismo e a discriminação e construir a paz social.

Na Europa ocidental, no início dos anos de 1980, o ideário das políticas estatais para o tratamento da diversidade cultural foi o da interculturalidade. Anunciando o 'surgimento' de uma 'nova' sociedade (globalizada, diversificada e informatizada) e, ao mesmo tempo, temendo tensões e conflitos sociais decorrentes da intensificação da crise econômica mundial e do aumento dos fluxos migratórios (ENZENSBERGER, 1993), esse ideário apontava a necessidade de uma política educacional que considerasse a existência de diferenças étnicas e culturais para a construção de uma 'nova' democracia liberal com ênfase na tolerância.

A interculturalidade, cuja ênfase incide sobre a relação entre as culturas, passou a ser vista como uma forma de promover a compreensão e o intercâmbio entre elas. Na Convenção sobre a Proteção e Promoção da Diversidade das Expressões Culturais (UNESCO, 2005, III, Art $4^{\circ}, \S 8$ ) o termo apresenta-se relacionado "[...] à existência e interação eqüitativa de diversas culturas, assim como à possibilidade de geração de expressões culturais compartilhadas por meio do diálogo e respeito mútuo".

O objetivo da política intercultural europeia foi minimizar os efeitos de práticas xenofóbicas e discriminatórias às quais estavam sujeitos os grupos minoritários, em razão do agravamento ainda maior da crise econômica e do desemprego. Um exemplo é o documento intitulado A Nova Política de Imigração, elaborado durante a presidência de Valéry Giscard d'Estaing (1974-1981) pelo Secretário de Estado encarregado dos trabalhadores imigrantes. Essa política, adotada no final dos anos de 1970 e no decorrer dos anos de 1980, tem por objetivo, segundo Cuche (2002, p.226), "permitir que os imigrantes tomem consciência de sua própria cultura ao mesmo tempo em que descubram a cultura francesa; ela procura também mostrar à população francesa a cultura dos países de origem destes imigrantes". Essa é uma estratégia para forçar um número significativo de imigrantes a regressar aos seus países de origem.

A partir de 1974, no contexto da crise mundial do capitalismo, foi determinado o fim oficial da política Office National d'Immigration, que vinha sendo adotada desde 1945 com a finalidade de atrair trabalhadores imigrantes, demarcando uma mudança na política governamental francesa. Para Cuche (2002), "da gestão da mão de obra estrangeira, passase à gestão da diferença cultural". Assim, "Gerir a diferença é, de certa forma, recusar a assimilação total dos imigrantes na nação francesa. Chega-se mesmo a pretender que os imigrantes não europeus são 'inassimiláveis', por serem diferentes culturalmente dos franceses". Desse modo, “ao promover a 'cultura dos imigrantes', os sucessivos governos deste período tentarão, através de todo o tipo de medidas de incentivo, provocar o regresso dos imigrantes a seus países" (CUCHE, 2002, p.226-227).

Assim, a partir dos anos de 1980, com a intensificação da luta dos imigrantes contra as discriminações e pela consolidação dos seus direitos e do aumento das manifestações racistas e xenófobas na sociedade francesa, a política da interculturalidade tinha o objetivo de enaltecer a identidade e a cultura dos imigrantes, demarcando-os e "fechando-os" em 
suas diferenças. Criou-se, assim, uma estratégia para reativar a 'consciência' de sua cultura de origem e incentivar o regresso aos seus países "[...] Contra todas as evidências, esperava-se que esse regresso se desse mais cedo ou mais tarde" (CUCHE, 2012, p.226227).

Outro exemplo dessa política cultural é a publicação do Livro Branco sobre o Diálogo Intercultural - Viver Juntos em Igual Dignidade pelos Ministros dos Negócios Estrangeiros do Conselho da Europa, por ocasião da sua $118^{a}$ reunião ministerial (Estrasburgo, 7 de Maio de 2008).

O Livro Branco propõe um modelo de gestão da diversidade cultural e contém orientações para uma boa atuação dos governos democráticos, das organizações da sociedade civil e dos cidadãos em geral. Tais orientações abrangem quatro principais áreas de atuação: a educação, a juventude, os meios de comunicação social e as migrações, prevendo ações para a cidadania participativa, o ensino e a aprendizagem de competências interculturais, a gestão dos espaços de diálogo intercultural e o diálogo intercultural nas relações internacionais (CARVALHO, 2012, p.90).

Esses encaminhamentos ensejaram discussões sobre diversidade cultural, linguística e identitária, aglutinando os centros decisórios do poder em torno de projetos para o controle e o monitoramento dos movimentos sociais de forma a minimizar os conflitos.

Os ideários ocidentais do multiculturalismo e da interculturalidade influenciaram as políticas públicas dos países periféricos, a exemplo dos latino-americanos. Na Conferência Mundial do México sobre Cultura e Desenvolvimento, realizada pela UNESCO no ano de 1982 com a presença de representantes de 126 países e de renomados pesquisadores, estabeleceu-se o compromisso de que políticas culturais deveriam ser elaboradas para humanizar as relações capitalistas, conforme consta no documento Declaración de México Sobre las Políticas Culturales.

Com o argumento de que a "comunidade das nações enfrenta também sérias dificuldades econômicas", que "a desigualdade entre as nações é crescente" e que "múltiplos conflitos e graves tensões ameaçam a paz e a segurança" (UNESCO, 1982, p.1), recomendou-se "harmonizar os conflitos internacionais" por meio da valorização das culturas locais, de grupos minoritários e de povos, ou seja, por meio da valorização da diversidade. Sugeriu-se também "estreitar a colaboração entre as nações", a fim de "preservar o patrimônio cultural" e "garantir a participação de todos na vida cultural" de modo a permitir "aos povos defender a sua soberania e independência e, por conseguinte, afirmar e promover sua identidade cultural" (UNESCO, 1982, p.4).

Nos documentos de afirmação dos princípios que devem reger essas políticas, a cultura é considerada "como o conjunto dos traços distintos, espirituais e materiais, intelectuais e afetivos que caracterizam uma sociedade ou grupo social. Ela engloba, além das artes e das letras, os modos de vida, os direitos fundamentais do ser humano, os sistemas de valores, as tradições e as crenças" (UNESCO, 1982, p.1). Relacionada a essa definição, a identidade cultural, apresentada como um "conjunto de valores único e insubstituível", já que as "tradições e as formas de expressão de cada povo constituem a forma mais acabada de estar no mundo", possibilitaria não apenas sua renovação e enriquecimento, mas, sobretudo, a afirmação das identidades e liberação dos povos (UNESCO, 1982, p.2).

A educação é tida como "o meio por excelência para transmitir os valores culturais nacionais e universais, e deve procurar a assimilação dos conhecimentos científicos e 
técnicos sem detrimento das capacidades e valores dos povos" (UNESCO, 1982, p.5).

De modo geral, os países que adotaram as medidas propostas pela UNESCO elaboraram uma reforma em sua lei maior (Constituição), reconhecendo os direitos culturais das minorias, e, na sequência, dirigiram o foco de ação para a reforma na política educacional, dando ênfase ao currículo, ao material didático diferenciado e à formação de professores (FAUSTINO, 2006).

Nessa agenda, a escola passa a ser tida como lócus privilegiado de disseminação das ideias de diversidade cultural, devendo assumir papel primordial na humanização do sistema capitalista. Recai sobre essa instituição e sobre os professores a responsabilidade por adotar práticas inclusivas, de respeito, tolerância e de valorização da diversidade, mesmo que não seja alterado o sistema econômico que produz miséria, violência e exclusão.

Entre a década de 1980 e a de 1990, outros documentos foram formulados, reiterando e detalhando as propostas de reforma pela via cultural e escolar. Iniciaram-se reformas constitucionais em todo o continente latino-americano com a aprovação e ou ampliação de direitos culturais. A Constituição Brasileira foi a primeira a ser aprovada (1988); nos demais países, os novos textos constitucionais foram aprovados no decorrer dos anos de 1990 (FAUSTINO, 2006).

No texto da Recomendação sobre a salvaguarda da cultura tradicional popular, aprovada em 1989, mencionam-se a importância e a extrema fragilidade de certas formas da cultura tradicional e popular, especialmente quanto aos aspectos relacionados à tradição oral. Alertando-se para o risco de que essa tradição se perca, ressalta-se a necessidade de sua preservação, divulgação e proteção por parte dos Estados membros. O caminho seria a "adopção de medidas legislativas ou de outra índole que sejam consideradas necessárias, em conformidade com as práticas constitucionais de cada Estado" (UNESCO, 1989, p.2).

Em 1998, em Estocolmo, ocorreu a Conferência Intergovernamental sobre Políticas Culturais para o Desenvolvimento, cujos principais propósitos foram:

1. Contribuir para a integração de políticas culturais nas estratégias de desenvolvimento humano em nível nacional e internacional; 2. Reforçar a contribuição da UNESCO para a formulação de políticas culturais e de cooperação cultural internacional (UNESCO, 1998a, p.1).

Dentre os objetivos que devem orientar os Estados membros em suas reformas, destacam-se: 1) fazer da política cultural um dos elementos-chave para as estratégias de desenvolvimento; 2) promover a criatividade e a participação na vida cultural; 4) promover a diversidade cultural e linguística na e para a sociedade da informação; 5) colocar mais recursos humanos e financeiros à disposição do desenvolvimento cultural (UNESCO, 1998, p.5-19).

Desse modo, observamos que, nos diferentes documentos, vai sendo reiterado o discurso da valorização da diversidade e construído um consenso sobre uma nova sociabilidade adequada à nova estratégia do capital de harmonização dos conflitos e manutenção das relações sociais.

O próximo item é destinado a uma abordagem de como a questão é apresentada nos documentos produzidos a partir da década de 1990, os quais indicam que a perspectiva de exaltação da diversidade cultural vem sendo mantida por meio de eventos e documentos periódicos por parte dos organismos e agências internacionais. Nesses documentos, embora nem todos sejam destinados à educação, esta é valorizada por seu papel estratégico na formação de novos valores e na divulgação dos ideais de respeito e valorização da diversidade cultural, ou seja, na construção de novas subjetividades e novos padrões de 
sociabilidade tendo em vista a convivência pacífica entre os povos em prol da harmonia social.

\section{As políticas educacionais internacionais de reconhecimento e valorização da diversidade cultural a partir dos anos de 1990}

Ao analisarmos os encaminhamentos das políticas educacionais a partir dos anos de 1990, não podemos desconsiderar as influências das organizações internacionais (OCDE, UNESCO, Banco Mundial, BID, dentre outros) ${ }^{10}$ na formulação e na legitimação das propostas, particularmente por meio de relatórios, boletins, recomendações, acordos, tratados, conferências organizadas mundialmente, "auxílio" técnico e financeiro. Estas seriam formas de dinamizar a difusão dos modelos, dos padrões de organização, das normas e das opções de reforma e, ao mesmo tempo, transformar, uniformizar e homogeneizar as linhas de ação da política em nível mundial.

A tendência cada vez maior de convergência no nível macro da retórica e das reformas políticas deve-se em grande parte aos efeitos dos processos de integração supranacional das economias e das políticas, ou seja, aos processos designados por globalização ou mundialização. Assim, constitui-se uma agenda globalmente estruturada (DALE, 2004) para as reformas, particularmente nos sistemas de educação dos diferentes países, tendo como fim a subordinação das instituições educacionais aos propósitos da economia global dirigida pelas economias centrais. Tal convergência decorre do fato de as políticas educacionais, ao longo da década de 1990, terem como antecedentes as recomendações internacionais sobre prioridades e estratégias e os compromissos assumidos pelos governos. Como são signatários de acordos transnacionais, os governos comprometem-se também com a aplicação e o cumprimento de metas, de modo que os projetos elaborados no âmbito da América Latina e do Caribe integram-se aos planos mundialmente acordados pelos países da região, que acabam por ter um caráter mandatário para as políticas nacionais (CAMPOS, 2008).

Considerando a influência das organizações internacionais na construção das políticas brasileiras, nas quais se destacam o reconhecimento e a valorização da diversidade, é necessário abordar esse direcionamento em alguns dos principais documentos produzidos por essas organizações.

Declaração de Princípios Sobre a Tolerância (1995). O ano de 1995 foi declarado pela UNESCO como o ano internacional da tolerância. Da discussão realizada nesse ano resultou a Declaração de Princípios Sobre a Tolerância, na qual foi revitalizada a ideia de tolerância elaborada por John Locke em 1689. Em sua Carta sobre a Tolerância, o teórico liberal ressaltou a prática da tolerância e do respeito à diversidade como um valor ético e como ação política para a melhor governabilidade.

Nesse documento de 1995, retomando os princípios liberais clássicos, a UNESCO reafirmou ideais de liberdade de pensamento, de expressão, de consciência e crenças, acrescentando-lhes as preocupações relacionadas à inclusão social e política e às ações para a diminuição da pobreza, dando atenção especial aos grupos social ou economicamente desfavorecidos. No documento, a intolerância é apresentada como a responsável pelos conflitos e violência, a tolerância, como a condição para a paz, para a democracia e o progresso econômico-social do capitalismo, no qual podem ser incluídos todos os povos. Em seguida, recomenda-se que os países membros tomem as medidas necessárias para promover a tolerância na sociedade. 
Considerando-se que, no âmbito dos Estados democráticos, "a tolerância exige justiça e imparcialidade na aplicação das leis e no exercício dos poderes judiciário e administrativo" (UNESCO, 1995, p.12), recomenda-se que, para instaurá-la, os "Estados devem ratificar as convenções internacionais relativas aos direitos humanos e se for necessário elaborar uma nova legislação a fim de garantir igualdade de tratamento e de oportunidades aos diferentes grupos e indivíduos da sociedade" (UNESCO, 1995, p.13).

No que diz respeito à educação, esta é considerada o meio mais eficaz de prevenir a intolerância. Nesses termos, tanto a educação formal (fornecida pelo sistema institucionalizado, envolvendo todos os níveis e modalidades de ensino) quanto a nãoformal (atividades extracurriculares organizadas por agências públicas e privadas de todos os tipos) desempenhariam um importante papel na formação de valores e atitudes em favor da paz e da coesão social.

No caso da educação não-formal, orienta-se: "Os meios de comunicação devem desempenhar um papel construtivo, favorecendo o diálogo e debate livres e abertos, propagando os valores da tolerância e ressaltando os riscos da indiferença à expansão das ideologias e dos grupos intolerantes" (UNESCO, 1995, p.14). No da educação formal, recomenda-se: "promover métodos sistemáticos e racionais de ensino da tolerância centrados nas fontes culturais, sociais, econômicas, políticas e religiosas da intolerância, que expressam as causas profundas da violência e da exclusão" (UNESCO, 1995, p.15).

[...] Por conseguinte, torna-se necessário dar atenção especial à melhoria da formação dos docentes, dos programas de ensino, do conteúdo dos manuais e cursos e de outros tipos de material pedagógico, inclusive as novas tecnologias educacionais, a fim de formar cidadãos solidários e responsáveis, abertos a outras culturas, capazes de apreciar o valor da liberdade, respeitadores da dignidade dos seres humanos e de suas diferenças e capazes de prevenir os conflitos ou de resolvê-los por meios não violentos (UNESCO, 1995, p.16).

Cumpre ressaltar que o discurso sobre a tolerância foi formulado pelos organismos internacionais com base nas ideias liberais do século XVIII, as quais sustentaram as violentas revoluções burguesas do período. Ressignificadas, essas idéias estão sendo utilizadas pelo capitalismo atual para controlar os movimentos sociais. A ideologia da tolerância tem como finalidade pacificar os povos, ensinando-os a suportar a pobreza, a melhorar a autoestima e valorizar sua identidade e a viver em harmonia, evitando conflitos.

Relatório Delors: Educação: um Tesouro a Descobrir (1996). Esse relatório, originalmente denominado Relatório da Comissão Internacional sobre Educação para o Século XXI, é um dos mais importantes documentos produzidos no campo da educação nos anos de 1990, em atenção a uma encomenda da UNESCO, que, para tal, contratou uma comissão internacional de especialistas coordenados por Jacques Delors.

Traduzido e divulgado em todos os países membros da Organização das Nações Unidas, sua finalidade era instituir uma política universal de educação que, baseada em uma filosofia liberal humanitária, formasse cidadãos tolerantes e aptos a viver em paz em um sistema produtor de desigualdades.

Nos termos do documento, "[...] todas as sociedades, seja qual for o seu estágio de desenvolvimento, ficarão sujeitas às tensões cada vez mais fortes enquanto a separação entre ricos e pobres continuar a aumentar e a tornar-se cada vez mais difícil de reduzir" (DELORS, 2001, p.242). Assim, só "Uma educação verdadeiramente multicultural deverá ser capaz de dar resposta, simultaneamente aos imperativos da integração planetária e 
nacional e às necessidades específicas das comunidades locais, rurais ou urbanas que têm a sua própria cultura [...]" (DELORS, 1998, p.249).

Acentuando a centralidade da educação e considerando que esta é responsável por garantir a empregabilidade, a participação democrática, o desenvolvimento sustentável, a tolerância, a paz, a coesão social e a superação de todas as formas de exclusão, os autores do documento definem os quatro pilares, ou bases, da educação: aprender a conhecer, aprender a fazer, aprender a viver juntos e aprender a ser. Tais princípios são indispensáveis na orientação e na definição de novas políticas educativas nos mais diversos países.

O aprender a viver juntos é considerado o principal deles (DELORS, 2001, p.19), já que um dos maiores desafios da educação é preparar o indivíduo para gerir conflitos latentes. Nesse princípio, estão implícitas duas formas de ação educacional. A primeira é levar o indivíduo à descoberta progressiva do outro, ao conhecimento da diversidade da espécie humana e à tomada de consciência das semelhanças e interdependências entre todos os seres humanos do planeta. A segunda, que se estende por toda a vida, caracterizase pela participação em projetos comuns, pelo estímulo à cooperação e à solidariedade, métodos eficazes para evitar ou resolver conflitos (DELORS, 2001). Os outros pilares também são "sustentáculos da educação que oferecem, de algum modo, os elementos básicos para aprender a viver juntos” (DELORS, 2001, p.20).

Relatório Cuéllar: Nossa Diversidade Criadora (1997). Esse relatório é resultante dos trabalhos da Comissão Mundial de Cultura e Desenvolvimento da UNESCO, composta por homens e mulheres de todas as regiões do mundo e coordenada por Javier Pérez de Cuéllar, representante do Peru junto à ONU. O documento faz parte das atividades propostas pela UNESCO para o Decênio Mundial para o Desenvolvimento Cultural, período de 1988 a 1997.

A proposta para esse decênio foi a de encontrar meios de redução da pobreza, sem alterar as bases de expansão e acumulação capitalista, o que explica que muitos estudos, documentos, investigações e publicações tenham sido produzidos sobre as relações entre cultura e desenvolvimento, dentre os quais o Relatório Cuéllar. O discurso que permeia esse documento é o da valorização da cultura como elemento estratégico para o desenvolvimento econômico dos países. Por essa razão, afirma-se que a cultura

[...] é, ao mesmo tempo, o veículo da transmissão do comportamento social, uma fonte dinâmica de transformação, de criatividades, de liberdade e do despertar de oportunidades e de inovação. Para grupos, tanto quanto para sociedades, cultura representa energia, inspiração, autonomia e capacitação, conhecimento e consciência da diversidade (CUÉLLAR, 1997, p.16).

Um dos aspectos centrais do relatório é a indissociabilidade entre o desenvolvimento humano e cultural e o desenvolvimento econômico.

[...] Nesse sentido, todas as formas de desenvolvimento - incluindo o desenvolvimento humano - são determinantes, em última análise, pelos fatores culturais. Dessa perspectiva, não faz sentido falar de "relação entre cultura e desenvolvimento", como se tratasse de dois conceitos separados e estanques, já que o desenvolvimento e economia fazem parte - ou são um aspecto - da própria cultura de um povo (CUÉLLAR, 1997, p.33). 
A diversidade cultural é entendida como base e recurso estratégico para o desenvolvimento econômico dos países da região, já que se podem "promover diferentes vias de desenvolvimento, com base no reconhecimento de que fatores culturais forjam os modos como as sociedades concebem seu próprio futuro e escolhem os meios para construí-los" (CUÉLLAR, 1997, p.16).

Com esta orientação, a "Comissão definiu várias áreas de políticas e ação para governos, organizações internacionais, associações privadas, empresas, sindicatos, famílias e indivíduos, que culminaram na Agenda Internacional" (CUÉLLAR, 1997, p.23), cujos objetivos são mobilizar energias e orientar a formulação de políticas.

Consta no relatório que a "pobreza, o desemprego, a fome, a ignorância, as doenças, a desnutrição e a exclusão são flagelos absolutos" e que "tais males são agravados por hábitos culturais que conduzem ao egoísmo estreito, ao preconceito e ao ódio irracional" (CUÉLLAR, 1997, p. 28). Por isso, a proposta é fazer do respeito e da tolerância para com todas as culturas, bem como da promoção de democracias multiétnicas e da proteção às minorias, meios para enfrentá-los.

Assim, caberia aos governos não "determinar a cultura de um povo", mas influenciá-la, modificando suas vias de desenvolvimento. “[...] O princípio básico deverá ser o respeito a todas as culturas cujos valores sejam suscetíveis de tolerância em relação aos de outras, e que aceitem a ética universal" Porém, o respeito "vai além da simples tolerância; implica em uma atitude positiva em relação aos outros, a satisfação relativa à diversidade de modos de vida e à sua diversidade criadora [...]" (CUÉLLAR, 1997, p.22).

A educação é concebida como uma ação integrada, não devendo, portanto, ser dissociada nem da cultura nem do desenvolvimento: "[...] As políticas do setor deveriam promover os aspectos humanísticos e produtivos da educação e incentivar a inovação e a criatividade" (CUÉLLAR, 1997, p.217).

Declaração do Milênio das Nações Unidas (2000). Elaborado ao longo de meses de discussões, esse documento reflete as preocupações de 147 chefes de estado e governo de 191 países. Conforme indicado no prefácio, os governantes propuseram-se a encontrar alternativas para enfrentar problemas comuns e "conseguir que a globalização venha a ser uma força positiva para todos os povos do mundo, uma vez que, se é certo que a globalização oferece grandes possibilidades, atualmente os seus benefícios, assim como os seus custos, são distribuídos de forma muito desigual” (ONU, 2000, p.2):

Os líderes definiram alvos concretos, como reduzir para metade a percentagem de pessoas que vivem na pobreza extrema, fornecer água potável e educação a todos, inverter a tendência de propagação do VIH/SIDA e alcançar outros objetivos no domínio do desenvolvimento. Pediram o reforço das operações de paz das Nações Unidas, para que as comunidades vulneráveis possam contar conosco nas horas difíceis. E pediram-nos também que combatêssemos a injustiça e a desigualdade, o terror e o crime, e que protegêssemos o nosso patrimônio comum, a Terra, em benefício das gerações futuras (ONU, 2000, PREFÁCIO).

Nessa declaração foi reafirmada a adesão dos dirigentes mundiais ao pleno reconhecimento dos direitos humanos e das liberdades fundamentais. O reconhecimento e o respeito à diversidade cultural, a tolerância, o diálogo, a cooperação e a solidariedade foram considerados como valores fundamentais para as relações internacionais e como meios de garantir a paz e a segurança internacional. 
Declaração Universal sobre Diversidade Cultural (2002). Essa declaração foi produzida depois dos acontecimentos de 11 de setembro de 2001 (UNESCO, 2004). Seu objetivo foi levar os Estados membros a adotar medidas para assegurar a preservação e a promoção da diversidade das culturas, tanto para garantir a paz quanto para promover o intercâmbio, a inovação e a criatividade.

Além de defender a diversidade cultural como "patrimônio comum da humanidade" (Art. 1), considerando que hoje as sociedades são cada vez mais diversificadas, o documento apresenta o pluralismo cultural como uma dimensão política indispensável "aos intercâmbios culturais e ao desenvolvimento das capacidades criadoras" (Art. 2).

A diversidade cultural não é apresentada como fonte de desenvolvimento apenas no sentido de crescimento econômico, mas também no intelectual, afetivo, moral e espiritual, porque amplia as possibilidades de escolha para todos. Os "bens e serviços culturais" são considerados como mercadorias distintas de outras, "uma vez que seriam portadores de identidade, valores e sentido" (Art.8).

Cada Estado deve assegurar "a livre circulação das idéias e das obras" e criar condições propícias para "a produção e a difusão de bens e serviços culturais diversificados, por meio de indústrias culturais que disponham de meios para desenvolverse nos planos local e mundial" (Art.9). Dado que "as forças do mercado, por si só, não poderiam garantir a preservação e promoção da diversidade cultural", recomenda-se "fortalecer a função primordial das políticas públicas, em parceria com o setor privado e a sociedade civil" (Art.11).

A UNESCO deve "promover a incorporação de tais princípios nas estratégias das entidades intergovernamentais", como também "servir de instância de referência e articulação entre os Estados, os organismos internacionais governamentais e nãogovernamentais, a sociedade civil e o setor privado para a elaboração conjunta de conceitos, objetivos e políticas em favor da diversidade cultural" (Art. 12).

Os demais artigos também são relevantes para a análise, já que contêm referências à importância da participação da iniciativa privada nas políticas de diversidade cultural.

Nas linhas gerais de um plano de ação para a aplicação da declaração é indicado que se deve: "Respeitar e proteger os sistemas de conhecimento tradicionais, especialmente os das populações autóctones; reconhecer a contribuição dos conhecimentos tradicionais para a proteção ambiental e a gestão dos recursos naturais e favorecer as sinergias entre a ciência moderna e os conhecimentos locais" (UNESCO, 2002, p.7).

Relatório de Desenvolvimento Humano (2004): Liberdade Cultural num Mundo Diversificado. Uma equipe de especialistas nomeada pelo Programa das Nações Unidas para o Desenvolvimento elaborou esse documento em defesa da liberdade cultural, considerando-a como um elemento essencial para o desenvolvimento das sociedades "cada vez mais diversificadas".

A liberdade cultural é uma parte vital do desenvolvimento humano, porque a capacidade de uma pessoa escolher a sua identidade - quem ela é - sem perder o respeito dos outros, ou ser excluída de outras opções, é importante para uma vida plena. As pessoas querem liberdade para praticar abertamente a sua religião, falar a sua língua, celebrar a sua herança étnica ou religiosa sem medo do ridículo, de punições ou da diminuição de oportunidades. As pessoas querem a liberdade de participar na sociedade sem ter de prescindir das amarras culturais que escolheram (UNESCO, 2004, p. 1). 
Nos termos do documento, essa é "uma ideia simples, mas profundamente perturbadora", tendo em vista que os "Estados enfrentam um desafio urgente na resposta a estas exigências" e, caso o assunto não seja adequadamente encaminhado e gerenciado, tais reivindicações "podem tornar-se rapidamente uma das maiores fontes de instabilidade dentro e entre os Estados - e, assim, desencadear conflitos que poderão fazer recuar o desenvolvimento" (UNESCO, 2004, p.1-2).

O fluxo migratório de pessoas pobres e desempregadas ocorrido no período da crise econômica do capitalismo mundial é considerado como resultado de situações de discriminação ${ }^{11}$. Em razão disso, reafirma-se a importância de políticas de reconhecimento e valorização da diversidade cultural, instando-se os Estados a adotar políticas de respeito e proteção aos grupos excluídos, de forma a promover a inclusão social, a estabilidade e a governação democrática.

No conjunto, tais prescrições denotam que a política de inclusão social tem sido considerada como uma maneira de cada Estado ter controle sobre as populações pobres, geralmente oriundos de regiões e países devastados pela exploração do capital.

Convenção sobre a proteção e promoção da diversidade das expressães culturais (2005). Nesta convenção, considera-se a "necessidade de incorporar a cultura como elemento estratégico nas políticas de desenvolvimento nacionais e internacionais" e de "proteger e promover a diversidade das expressões culturais", particularmente nas "situações em que as expressões culturais possam estar ameaçadas de extinção ou de grave deteriorização". Pondera-se que os processos de globalização intensificam a interação entre as culturas, mas também constituem um desafio "especialmente no que diz respeito aos desequilíbrios entre países ricos e países pobres" (UNESCO, 2005, p.2).

Reconhecendo-se a "dupla natureza, tanto econômica quanto cultural" das atividades, bens e serviços culturais e, ao mesmo tempo sua especificidade "enquanto portadores de identidades, valores e significados" (UNESCO, 2005, p.3), reafirma-se "o direito soberano dos Estados de conservar, adotar e implantar políticas e medidas que considerem apropriados para a proteção e a promoção da diversidade das expressões culturais em seu território" (UNESCO, 2005, p.4). A sociedaide civil e a cooperação internacional são destacadas como elementos importantes na proteção e na promoção da diversidade.

No Art. 10 do texto, fica estabelecido que as partes devem: "propiciar e desenvolver a compreensão da importância da proteção e promoção da diversidade das expressões culturais, por intermédio, entre outros, de programas de educação e maior sensibilização do público" (UNESCO, 2005, p.7). Esse documento tornou-se um instrumento jurídico sobre o patrimônio cultural e a diversidade, uma referência para as medidas adotadas pelos Estados Membros da UNESCO.

\section{Relatório Investir na Diversidade Cultural e no Diálogo Intercultural (2010).}

Centralizando-se nas vantagens da diversidade cultural para a comunidade internacional, esse relatório tem como objetivo

[...] convencer os decisores e as diferentes partes intervenientes sobre a importância em investir na diversidade cultural como dimensão essencial do diálogo intercultural, pois ela pode renovar a nossa percepção sobre o desenvolvimento sustentável, garantir o exercício eficaz das liberdades e dos direitos humanos e fortalecer a coesão social e a governança democrática (UNESCO, 2010, p.1). 
Em uma renovação das orientações do Relatório Cuéllar (1997), afirma-se que "a diversidade cultural não era simplesmente um bem que se deveria preservar, antes consistia num recurso a fomentar, tendo em vista os seus potenciais dividendos, nomeadamente em âmbitos relativamente distanciados de um entendimento estrito de cultura" (UNESCO, 2010, p.1). As políticas educacionais teriam uma

[...] repercussão decisiva no florescimento ou no declínio da diversidade cultural e devem promover a educação pela e para a diversidade. Assim se garante o direito à educação, ao mesmo tempo em que se reconhece a diversidade das necessidades dos educandos (especialmente daqueles que pertencem a grupos minoritários, indígenas ou nômades) e a variedade dos métodos e conteúdos conexos. Em sociedades multiculturais cada vez mais complexas, a educação deve auxiliar-nos a adquirir as competências interculturais que nos permitam conviver com as nossas diferenças culturais e não apesar delas (UNESCO, 2010, p.15).

Em face do exposto, reiteramos que as políticas voltadas à diversidade cultural adquiriram grande relevância. Tiveram um papel social de destaque nas últimas três décadas, especialmente quanto à finalidade explícita de constituir novos significados e de orientar o comportamento social tendo em vista a harmonização das relações sociais e a continuidade do sistema capitalista. Na área da Educação, as reformas ocorridas a partir dos anos de 1990 no mundo todo, fundando-se nos princípios de reconhecimento e de valorização da diversidade cultural, definiram e padronizaram diretrizes e práticas educativas.

Os eventos, documentos e financiamentos condicionaram a adesão dos países membros às prescrições internacionais e, assim, por meio de consensos e de conformação ao novo projeto de sociabilidade, foi sendo construída uma hegemonia discursiva que direciona as ações a sustentar a estratégia de manutenção e de expansão do capitalismo em diferentes regiões do mundo. Esse projeto é explicitado por Cuéllar (1997, p.16):

O desafio enfrentado pela humanidade é o de adotar novas formas de pensamento, novos modos de ação, novas modalidades de organização social, em suma, novos estilos de vida. O desafio é também o de promover diferentes vias de desenvolvimento, com base no reconhecimento de que fatores culturais forjam os modos como as sociedades concebem seu próprio futuro e escolhem os meios de construí-los.

Fica evidente, portanto, que, no mundo globalizado, essa proposta de educação, que exalta a especificidade e a diversidade de indivíduos e dos grupos humanos, constitui uma estratégia de coesão e desenvolvimento sociais.

No que se refere ao Brasil, por influência dos organismos e agências internacionais, uma ampla legislação educacional com foco na diversidade cultural vem sendo construída, sobretudo a partir dos anos de 1990, redefinindo o conteúdo escolar e a ação pedagógica. Nas diretrizes curriculares nacionais para os diferentes níveis de ensino, os princípios, fundamentos e procedimentos norteadores das ações pedagógicas nas escolas foram estabelecidos com base na autonomia, na responsabilidade, na solidariedade e no respeito ao bem comum e à ordem democrática e na valorização da diversidade de manifestações artísticas e culturais (BRASIL, 1998a; 1998b; 1999; 2006).

Entretanto, considerando o caráter contraditório e conflituoso da sociedade, cabenos pensar o tema de outra perspectiva. 


\section{Considerações para o debate}

As organizações internacionais, particularmente a UNESCO, sobre os pilares do ideário do respeito e da tolerância como condição indispensável para a convivência pacífica e harmoniosa entre os diferentes povos e classes sociais em "um mundo globalizado", instituíram e divulgaram amplamente, a partir dos anos de 1990, a política de reconhecimento e valorização da diversidade.

Entretanto, essa política, ao mesmo tempo em que promove a valorização da diversidade cultural como primazia da convivência social, consolida e aprofunda "o individualismo como valor moral mais radical, uma vez que reúne os indivíduos para tratar de seus problemas mais específicos, desvinculados das questões mais gerais" (NEVES; SANT'ANNA, 2005, p.36). Ao fazê-lo, deixa resguardados os processos de exploração econômica que submetem imensos contingentes populacionais a uma situação de exclusão e discriminação.

As políticas voltadas à diversidade enfatizam o apaziguamento das relações sociais e dos conflitos como algo que depende, antes de tudo, do compromisso e da responsabilidade dos indivíduos que integram a sociedade, desconsiderando que esses compromissos envolvem relações de classe, de poder e o combate aos privilégios e à desigualdade econômica e social,

$\mathrm{Na}$ perspectiva dos documentos, a cultura torna-se uma categoria central na resolução dos problemas sociais. Conforme podemos identificar no Relatório Cuéllar (1997, p.16):

Nosso propósito é mostrar a todos como a cultura forja todo nosso pensamento, nossa imaginação e nosso comportamento [...] Se a diversidade cultural está "atrás de nós, ao nosso redor e à nossa frente", como afirma Claude Lévi-Strauss, devemos aprender como fazê-la conduzir não ao conflito de culturas, mas à coexistência frutífera e à harmonia intercultural.

Nessa defesa da harmonia cultural não estão contemplados os aspectos que impedem que haja harmonia e igualdade econômica e política. Conforme Eagleton (2005, p.183):

[...] Os problemas básicos com que nos defrontamos no novo milênio guerra, fome, pobreza, doenças, endividamento, drogas, poluição ambiental, o desenraizamento de povos - não são em absoluto especialmente "culturais". Eles não são basicamente uma questão de valores, simbolismo, linguagem, tradição, pertinência ou identidade, e muito menos uma questão de artes.

Isso significa que, nesses documentos, não está contemplado o fato de que os maiores problemas que afetam os povos são de ordem material. Se houver condições de vida adequadas para todos, os povos e grupos diferenciados desenvolverão suas próprias estratégias de preservação e difusão de suas culturas conforme suas próprias decisões, sem precisar que organismos e agências internacionais ocidentais, mantenedoras da ordem social vigente, prescrevam ações padronizadas de valorização das culturas.

De nossa perspectiva, são intrínsecas à forma de organização da sociedade capitalista as mudanças que intensificam a competição e agravam as desigualdades e a exclusão social, produzindo comportamentos sociais relacionados a novas formas de 
intolerância, violência, racismo, xenofobia, manifestação do nacionalismo, marginalização, discriminação. Nesse processo, estão envolvidos não apenas as minorias étnicas, as mulheres, e algumas orientações sexuais, mas também algumas tendências religiosas e linguísticas e as novas formas de terrorismo.

Observamos que, longe de tornar as desigualdades e conflitos sociais objeto de reflexão, a educação, como apresentada nessas discussões, está sendo convocada a preparar os indivíduos para a acirrada competitividade e, ao mesmo tempo, a promover a tolerância e a solidariedade (DELORS, 2001), como se esses valores, ao serem assumidos pelos sujeitos nos limites das individualidades, pudessem promover a paz e a segurança almejada.

Por consequência, tal projeto de educação oculta as contradições sociais e rejeita qualquer intervenção dos homens contra a desigualdade real. Ao fazê-lo, segundo Nagel (2007), passa a defender relações harmoniosas e de tolerância entre as classes e grupos sociais, que, nesta sociedade, têm interesses antagônicos. Consideramos que a tolerância, o reconhecimento, o respeito e a aceitação das diferenças, em nome da paz social, não resultam necessariamente na inclusão social e sim na ocultação e reprodução das desigualdades econômicas, na ausência de liberdade e na exploração. Nesse sentido, concordamos com Rodrigues e Abramowicz (2013, p.18), quando afirmam que "a diversidade foi entendida como uma forma de governamento exercido pela política pública no campo da cultura, como uma estratégia de apaziguamento das desigualdades"; que a "diversidade esvazia a diferença, pois o diverso contém em si a ideia de identidades que se relacionam, compõem-se e toleram-se como se fosse possível estabelecer diálogos igualitários sem as hierarquias de poder/saber [...]"; que a diversidade, ao mesmo tempo, "significa manter intactas as hierarquias do que é considerado hegemônico".

Outro aspecto importante é apontado por Neves e Sant'Anna: desconsiderar que os problemas parecem decorrer de causas outras que não necessariamente a lógica do capital restringe a consciência política da classe trabalhadora. Assim,

[...] As lutas concebidas exclusivamente em termos extra-econômicos, portanto, não representam, em si mesmas, um perigo fatal para o capitalismo. Podem, inclusive, ser funcionais à estabilização da hegemonia burguesa. Politicamente, portanto, a organização desses grupos acaba por, contraditoriamente, desviar a atenção de importantes segmentos da classe trabalhadora da reflexão de mecanismos de expropriação e exploração a que estão submetidos [...] (NEVES, SANT'ANNA, 2005, p.36).

Além disso, em nossa análise das políticas de valorização da diversidade, chegamos à conclusão de que elas podem ser identificadas como uma estratégia do capital na busca por novos mercados. É significativo que o discurso da defesa da diversidade ganhe ênfase no contexto de avanço da globalização econômica, de flexibilização produtiva, o qual implica a necessidade de produzir bens diversificados e ampliar as possibilidades de escolhas do consumidor (CARVALHO, 2012).

À medida que as forças do mercado penetram mais profundamente na produção cultural, a diversidade é vista como uma forma de fomentar a criação e a inovação que lhes são necessárias. Isso pode ser confirmado nos documentos analisados: Declaração Universal sobre a Diversidade Cultural (UNESCO, 2002), Relatório de Desenvolvimento Humano (2004) - Liberdade Cultural num Mundo Diversificado e a Convenção sobre a proteção e promoção da diversidade das expressões culturais (2005) e, mais recentemente, o Relatório Investir na Diversidade Cultural e no Diálogo Intercultural (2010). 
[...] a diversidade cultural tornou-se fator essencial que se deve levar em consideração nas operações comerciais em nível mundial. As multinacionais estão cada vez mais conscientes dos benefícios que podem obter com a diversificação e a adaptação de seus produtos para penetrar em novos mercados e responder às expectativas dos consumidores locais (UNESCO, 2010, p.22).

Portanto, como um fator determinante nos resultados econômicos e um recurso a ser promovido no âmbito dos países, "a diversidade é a palavra-chave da possibilidade de ampliar o campo do capital, que penetra cada vez mais em subjetividades antes intactas. Vendem-se produtos para as diferenças e, nesse sentido, é preciso incentivá-las" (RODRIGUES; ABRAMOWICK, 2013, p.18).

De nossa perspectiva, o debate que envolve a educação intercultural deve ter em conta não apenas a luta pelo reconhecimento das diferenças, as quais são vinculadas a interesses tópicos e imediatos, mas também as causas sócio-históricas das divisões entre os homens. O contrário significa obscurecer o entendimento de como as relações sociais se constituem, contribuindo, em última instância, para a aceitação das diferenças e não para a superação das condições que as produzem. Nesse sentido, cabe lembrar Duarte (2004, p.55):

Aqueles que pensam que desenvolvem mecanismos de resistência à mundialização do capitalismo por meio da defesa dos direitos das chamadas minorias e da defesa do multiculturalismo não perceberam que a dinâmica da universalização do mercado possui uma plasticidade que lhes permite assimilar os fenômenos culturais locais, transformando-os em mercadorias e utilizando-se deles de forma ideológica, para legitimar do ponto de vista ético a manutenção das desigualdades socais [...] Em nome do respeito à alteridade e da convivência pacífica entre os povos e entre os grupos culturais são perpetuadas as divisões e exclusões necessárias à reprodução do capital [...]

O grande desafio que atualmente se impõe aos intelectuais e educadores é o de aprofundar a compreensão teórica desse fenômeno histórico e reavaliar sua própria atuação no interior das instituições educacionais.

\section{Referências}

AHMAD, A.. Linhagens do presente: ensaios. Tradução por: Sandra Guardini Vasconcelos. São Paulo: Boitempo, 2002.

BRASIL. Parâmetros curriculares nacionais: pluralidade cultural, orientação sexual. Brasília, DF: MEC/SEF, 1997. v. 10.

Resolução CEB/CNE $\mathbf{n}^{\mathbf{0}}$ 2, de 7 de abril de 1998a. Institui as diretrizes curriculares nacionais para o ensino fundamental. Disponível em: 〈http://portal.mec.gov.br/cne/arquivos/pdf/rceb02_98.pdf>. Acesso em: 02 mar. 2008.

. Parecer CEB no 04/98, 29 de janeiro de 1998b. Assunto: Diretrizes Curriculares $\begin{array}{lcccc}\text { Nacionais } & \text { para } & 0 & \text { Ensino } & \text { Fundamental. }\end{array}$

Resolução CEB/CNE $\mathbf{n}^{\mathbf{0}} \mathbf{3}$, de 26 de junho de 1998. Institui as diretrizes 
curriculares nacionais para o ensino médio. Disponível em: <http://portal.mec.gov.br/cne/arquivos/pdf/rceb03_98.pdf >. Acesso em: 02 mar. 2008.

BERGMANN, B.. In defense of affirmative action. New York: BasicBooks, 1996.

BRASIL. Referencial curricular nacional para as escolas indígenas. Ministério da Educação e do Desporto. Brasília. 1998.

CAMPOS, R.. Educação Infantil e Organismos Internacionais: uma análise dos projetos em curso na América Latina e suas repercussões no contexto nacional. 215f. 2008. Tese (Doutorado) - Programa de Pós-Graduação em Educação da Universidade Federal de Santa Catarina.

CARVAlHO, E. J.G.. Diversidade Cultural e Gestão Escolar: Alguns Pontos para Reflexão. Rev. Teoria e Prática da Educação, v. 15, n. 2, p. 85-100, maio./ago. 2012.

CUCHE, D. A noção de cultura nas ciências sociais. $2^{\mathrm{a}}$ ed. Bauru: EDUSC, 2002.

CUÉLlAR, J. P. (Org.). Nossa diversidade criadora: Relatório da Comissão Mundial de cultura e desenvolvimento. Campinas: Papirus; Brasília, DF: Unesco, 1997.

DALE, R.. Globalização e educação: demonstrando a existência de uma 'cultura educacional mundial comum' ou localizando uma 'agenda globalmente estruturada para a educação’? Revista Educação, Sociedade \& Culturas, Porto, n. 16, p. 133-169, 2001.

DELORS, J. (Org.). Educação: um tesouro a descobrir. 3. ed. São Paulo: Cortez, 2001. Relatório para a UNESCO da Comissão Internacional Sobre a Educação Para o Século XXI.

DUARTE, N.. Vigotski e o "aprender a apernder": críticas as proposições neoliberais e pós-modernas da teoria vigostskiana. $3^{\mathrm{a}}$ ed., Campinas, SP, Autores Associados, 2004.

CALLINICOS, A.. Igualdad y capitalismo. In: BORON, A. A.; AMADEO, J.; GONZÁLEZ (Comps.) La teoría marxista hoy. Buenos Aires: CLACSO, 2006.

EAGLETON, T.. A idéia de cultura. Tradução por: Sandra Castello Branco. São Paulo: Editora UNESP, 2005.

ENZENSBERGER. H. M.. O vagão humano. Reflexões para o século XXI. Veja (Edição 25 anos). São Paulo, 1993.

FAUSTINO, R. C.. Política educacional nos anos de 1990: o multiculturalismo e a interculturalidade na educação escolar indígena. 334 f. 2006. Tese (Doutorado) Programa de Pós-Graduação em Educação da Universidade Federal de Santa Catarina.

HARVEY, D.. O neoliberalismo: história e implicações. $2^{a}$ ed, São Paulo, edições Loyola, 2011.

KRUPER, A.. Cultura: a visão dos antropólogos. Bauru-SP: EDUSC, 2002.

LÈVI-STRAUSS, C.. Raça e História. In: LÈVI-STRAUSS, C.. Antropologia Estrutural II. Rio de Janeiro: Tempo Brasileiro, 1976.

NAGEL, L. H.. O 'aqui e o agora', sem 'ontem e o amanhã', nas políticas da educação. In: NOGUEIRA, F. M. G.; RIZOTTO, M. L. F. (Org.). Estado e políticas sociais: Brasil - Paraná. Cascavel: Edunioeste, 2003. p. 29-40.

NEVES, L. M. W.; SANT'ANNA, R.. Introdução: Gramsci, o Estado Educador e a Nova Pedagogia da Hegemonia. In: A Nova Pedagogia da Hegemonia: estratégias do capital 
para educar para consenso. NEVES, L. M. W. (Org.), São Paulo, Xamã, 2005, p. 18-39. OLIVEIRA, E. de; SOUZA, M. L. de. Multiculturalismo, diversidade cultural e direito coletivo na ordem contemporânea. Cadernos da Escola de Direito e Relações Internacionais. Curitiba. v. 1, n. 15, p. 121-139, 2011. Disponível em:

$<$ http://apps.unibrasil.com.br/revista/index.php/direito/article/viewFile/806/69>. Acesso em: $14 / 01 / 2015$.

RAYMOND, W.. Cultura e sociedade: de Coleridge a Orwell. Petrópolis, RJ, Vozes, 2011.

RODRIGUES, T. C.; ABRAMOWICK, A.. O debate contemporâneo sobre a diversidade e a diferença nas políticas e pesquisas em educação. Educ. Pesqui., São Paulo, v. 39, n. 1, p. 15-30, jan./mar. 2013.

SILVA, L. F.. Cultura, políticas culturais: O papel da UNESCO na discussão contemporânea. GT - 32 Sociologia del Arte y la Cultura, s/da. Disponível em: actacientifica.servicioit.cl/biblioteca/gt/GT32/GT32_DaSilvaL.pdf Acesso em: 14 de abr. de 2014.

SILVA, L. F.. Cultura, políticas culturais e UNESCO: Sobre a relação entre imperialismo e cultura no capitalismo contemporâneo GT - 8 Cultura, capitalismo e Socialismo. $\quad \mathrm{s} / \mathrm{db}$ Disponível em: www.ifch.unicamp.br/.../7082_Da\%20Silva_Luiz\%20Fernando.pdf Acesso em: 14 de abr. de 2014.

UNESCO. The race question. UNESCO Publication 791. Paris, 1950. Disponível em: http://unesdoc.unesco.org/images/0012/001282/128291eo.pdf Acesso em: 7 de nov. de 2014.

Declaración de México sobre las Políticas Culturales. Conferencia mundial sobre las políticas culturales. México D.F., 26 de julio - 6 de agosto de 1982. Disponível em:

http://portal.unesco.org/culture/es/files/35197/11919413801mexico_sp.pdf/mexico_sp.pdf Acesso em: 7 de nov. de 2014.

Declaración de Ciudad de México: Conferencia Regional de Ministros de Educación y de Ministros Encargados de la Planificación Económica de los Estados Miembros de América Latina y el Caribe. México, 4-13 de diciembre de 1979. Disponível em: http://unesdoc.unesco.org/images/0015/001599/159987S.pdf Acesso em: 7 de nov. de 2014. v. $1,65 p$.

Records of the General Conference Fourth extraordinary session. Paris, 1982, Disponível

Recomendação sobre a salvaguarda da cultura tradicional popular. 1989. www.matrizpci.dgpc.pt/.../CommonServices/FileDownloader.axd?...Reco... Acesso em: 7 de nov. de 2014.

Intergovernmental Conference on Cultural Policies for Developement. 1998a. Disponível em: http://www.unesco.org/es/cultural-diversity/the-stockholm-conference/ Acesso em: 14 de jan. de 2015.

\section{Conferencia Intergubernamental sobre Políticas Culturales para el}


Desarrollo. Infrome $\quad$ Final. 1998b. Disponível em: http://unesdoc.unesco.org/images/0011/001139/113935so.pdf Acesso em: 14 de jan. de 2015.

. Declaração de princípios sobre a tolerância (1995). Disponível em: <http://unesdoc.unesco.org/images/0013/001315/131524PORb.pdf>. Acesso em: 23 maio 2008.

Rapport Mondial sur la Culture. Diversité culturelle, conflit et pluralisme. Paris: Éditions $2000 . \quad$ Unesco, Disponível em: http://unesdoc.unesco.org/images/0012/001224/122411F.pdf

UNESCO and the issue of cultural diversity: review and strategy 1946-2000. Division of Cultural Policies. UNESCO, 2004. Disponível em: http://www.itigermany.de/fileadmin/user_upload/pdf_theater/4_Die_Konvention.pdf Acesso em: 16 de jan. de 2015.

Declaração universal sobre a diversidade cultural (2002). Disponível em: $<$ http://unesdoc.unesco.org/images/0012/001271/127160por.pdf $>$. Acesso em: 23 maio 2008.

A UNESCO no Brasil: consolidando compromissos. Brasília: UNESCO, 2004.

. Convenção sobre a proteção e promoção da diversidade das expressões culturais. (2005). Disponível em: http://unesdoc.Unesco.org/images/0014/001429/142919s.pdf. Acesso em: 03 de abr. de 2014.

Relatório Mundial da UNESCO: Investir na Diversidade Cultural e no Diálogo Intercultural $\quad-\quad$ Resumo (2010). Disponível em: unesdoc.unesco.org/images/0018/001847/184755por.pdf Acesso em: 14 de jan. de 2015.

WOOD, E. M.. Democracia contra capitalismo: a renovação do materialismo histórico. São Paulo: Boitempo, 2003.

\footnotetext{
* Professora da Área de Políticas Públicas e Gestão da Educação do Departamento de Teoria e Prática da Educação e do Programa de Pós-Graduação em Educação da Universidade Estadual de Maringá. E-mail elmajulia@ hotmail.com

* Professora da Área de Didática e Metodologia do Ensino do Departamento de Teoria e Prática da Educação e do Programa de Pós-Graduação em Educação da Universidade Estadual de Maringá. E-mail rcfaustino@uem.br

${ }^{1}$ Elgleton (2005, p.11) observa que: “[...] Cultura é uma dessas raras ideias que têm sido tão essenciais para a esquerda política quanto vitais para a direita, o que torna sua história social excepcionalmente confusa e ambivalente".

${ }^{2}$ A Declaração do México expressa a ampliação do conceito de cultura: "É a cultura que nos torna humanos, especialmente os seres relacionais, dotados de um julgamento crítico e um senso de compromisso moral. É por meio da cultura que nós podemos discernir valores e fazer escolhas. É por meio da cultura que o homem se expressa, torna-se consciente de si mesmo, reconhece sua incompletude, questiona suas próprias realizações, procura incansavelmente novos significados e cria obras por meio das quais transcende suas limitações" (UNESCO, 2000, p.14).

${ }^{3} \mathrm{Em}$ estudo produzido com base em seus documentos oficiais, intitulado UNESCO e a questão da diversidade cultural: revisão e estratégia 1946-2000, são identificados quatro temas, relacionados tanto ao conteúdo do discurso quanto à ênfase ao conceito de diversidade cultural: 1) cultura e conhecimento; 2) cultura e política; 3) cultura e desenvolvimento; 4) cultura e democracia (UNESCO, 2004).
} 


\begin{abstract}
${ }^{4} \mathrm{Na}$ Declaração de Constituição da UNESCO, aprovada em 15 de novembro de 1945, está registrado que "a grande e terrível guerra que acaba de terminar não teria sido possível sem a negação dos princípios democráticos da igualdade, da dignidade e do respeito mútuo entre os homens, e sem a vontade de substituir tais princípios, explorando os preconceitos e a ignorância, pelo dogma da desigualdade dos homens e das raças" (Preâmbulo). Consta também que, por isso, organização "se propõe a contribuir para a paz e para a segurança, estreitando mediante a educação e a cultura, a colaboração entre as nações, a fim de assegurar o respeito universal à justiça, à lei, e aos direitos humanos e às liberdades fundamentais que sem distinção de raça, sexo, idioma ou religião" (UNESCO, 1945, art.1).
\end{abstract}

${ }^{5}$ Callinicos (2006, p.266) observa que, no pensamento liberal igualitário, "[...] se define a justiça como eqüidade segundo dois princípios: a igual distribuição de uma lista bem conhecida de liberdades civis e políticas e o famoso "Princípio da Diferença", de acordo com o qual as desigualdades sociais e econômicas só são justificáveis quando redundam em benefício dos setores mais despossuídos da sociedade".

${ }^{6}$ Conforme Faustino (2006), nessa carta, Locke considera as condições de opressão, miséria e exclusão dos benefícios da lei às quais estava submetida grande parte da população, alerta os soberanos sobre o perigo das revoltas e insurreições e afirma as vantagens políticas da tolerância como um elemento integrador. Por compreender que a intolerância, e não a diversidade de opiniões e crenças, era responsável pelas discórdias e guerras civis, ele manifesta sua opinião de que o Estado muito se beneficiaria se o soberano tolerasse as diferenças culturais e as organizações populares que desejavam ser reconhecidas, ao invés de perseguir e castigar os "incendiários e perturbadores" da paz pública. Como forma de evitar que a ordem civil fosse ameaçada, ele orienta os governantes a convidá-los à participação política, como também a suprimir as discriminações em matéria civil e alterar a legislação para incluir todos os povos no direito à cidadania. Locke afirmou que, ao serem estabelecidos os princípios da tolerância, os tumultos, as animosidades contra o poder do Estado e as dissidências desapareceriam e, em seu lugar reinaria nas organizações populares o espírito mais pacífico e menos suscetível a perturbações públicas.

7 Segundo Barbara Bermann (1996), ação afirmativa é planejar e atuar no sentido de promover a representação de certos tipos de pessoas, especialmente aquelas pertencentes a grupos excluídos dos direitos sociais.

${ }^{8}$ Essa convenção foi adotada no Brasil pelo Decreto $n^{\circ}$ 6565. 810, de 8 de dezembro de 1969.

${ }^{9}$ Essa convenção foi adotada pela Resolução n. 34/180 da Assembléia Geral das Nações Unidas, em 18 de dezembro de 1979, e ratificada no Brasil em $1^{\circ}$ de fevereiro de 1984.

${ }^{10}$ Conforme Frigotto e Ciavatta (2003, p.96): "Os protagonistas destas reformas seriam os organismos internacionais e regionais vinculados aos mecanismos de mercado e representantes encarregados, em última instância, de garantir a rentabilidade do sistema capital, das grandes corporações, das empresas transnacionais e das nações poderosas onde aquelas têm suas bases e matrizes. Nesta compreensão, os organismos internacionais, como o Fundo Monetário Internacional (FMI), o Banco Mundial (BIRD), o Banco Interamericano de Desenvolvimento (BID) e o Programa das Nações Unidas para o Desenvolvimento (PNUD), passam a ter o papel de tutorear as reformas dos Estados nacionais, mormente dos países do capitalismo periférico e semiperiférico (Arrighi, 1998). No plano jurídico-econômico, a Organização Mundial do Comércio (OMC) vai tecendo uma legislação cujo poder transcende o domínio das megacorporações e empresas transnacionais. É interessante ter presente o papel da OMC, pois, em 2000, em uma de suas últimas reuniões, sinalizou para o capital que um dos espaços mais fecundos para negócios rentáveis era o campo educacional".

${ }^{11}$ Conforme consta no relatório (UNESCO, 2004, p.87), "As pessoas sempre atravessaram fronteiras, mas os números têm crescido ao longo das últimas três décadas. O número de migrantes internacionais - pessoas que vivem fora do seu país natal - aumentou de 76 milhões em 1960 para 154 milhões em 1990 e 175 milhões em 2000 [...] Em relação à Europa Ocidental, Austrália e América do Norte, o crescimento da migração na última década concentrou-se quase inteiramente em fluxos dos países pobres para os países ricos. Na década de 1990, a população estrangeira nas regiões mais desenvolvidas aumentou em 23 milhões [...] Hoje, quase 1 de cada 10 pessoas que vivem nesses países nasceu noutro sitio [...] Migração clandestina. Atingiu níveis sem precedentes: mais de 30 milhões de pessoas em todo o mundo não têm estatuto de residência legal nos países onde vivem".

Recebido: $\quad$ março-15 Aprovado: abril-15 